\title{
CORRECTION
}

\section{Correction to: Intravenous Ferric Carboxymaltose in Patients with Type 2 Diabetes Mellitus and Iron Deficiency: CLEVER Trial Study Design and Protocol}

\author{
Christoph Schindler · Andreas L. Birkenfeld · Markolf Hanefeld · \\ Ulrike Schatz · Carsta Köhler · Martin Grüneberg • Diethelm Tschöpe · \\ Matthias Blüher · Christoph Hasslacher · Stefan R. Bornstein
}

Published online: December 6, 2018

(C) The Author(s) 2018

Correction to: Diabetes Ther (2018) 9:37-47

https://doi.org/10.1007/s13300-017-0330-z

In the original publication, the text in Table 2 stated 'Hypersensitivity to the active substance, to Ferinject, or to any of its excipients'. The authors would like to make changes to the text and have replaced it to 'Hypersensitivity to ferric carboxymaltose or to any of the excipients of the study medication'. The authors have also made alterations to Fig. 1. Corrected Fig. 1 and Table 2 are given below:

The original article can be found online at https://doi. org/10.1007/s13300-017-0330-z.

C. Schindler $(\bowtie)$

Clinical Research Center Hannover and Center for Pharmacology and Toxicology, Hannover Medical School, Hannover, Germany

e-mail: schindler.christoph@mh-hannover.de

A. L. Birkenfeld · U. Schatz · S. R. Bornstein Medical Clinic and Policlinic III at the University Hospital Dresden, Dresden, Germany

\section{A. L. Birkenfeld · M. Hanefeld}

Centre for Metabolic Vascular Medicine, GWT-TUD, Dresden, Germany

C. Köhler

Medical Consulting, GWT-TUD, Dresden, Germany

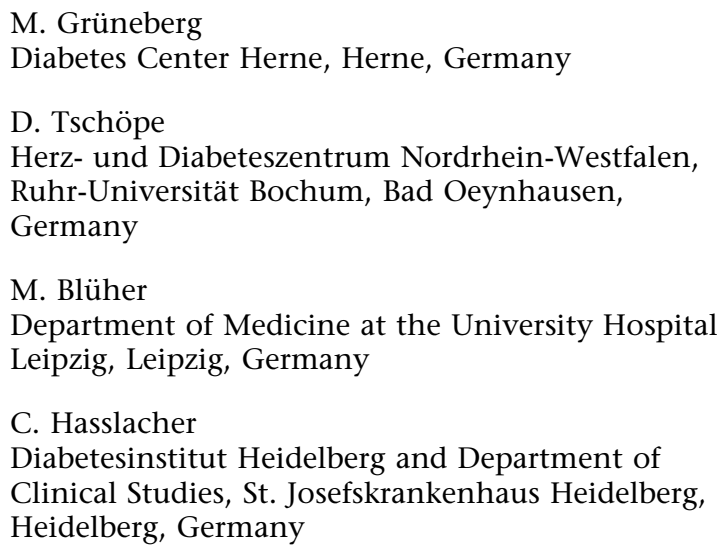
Ruhr-Universität Bochum, Bad Oeynhausen, Germany

M. Blüher

Department of Medicine at the University Hospital Leipzig, Leipzig, Germany

C. Hasslacher

Diabetesinstitut Heidelberg and Department of Clinical Studies, St. Josefskrankenhaus Heidelberg, Heidelberg, Germany 


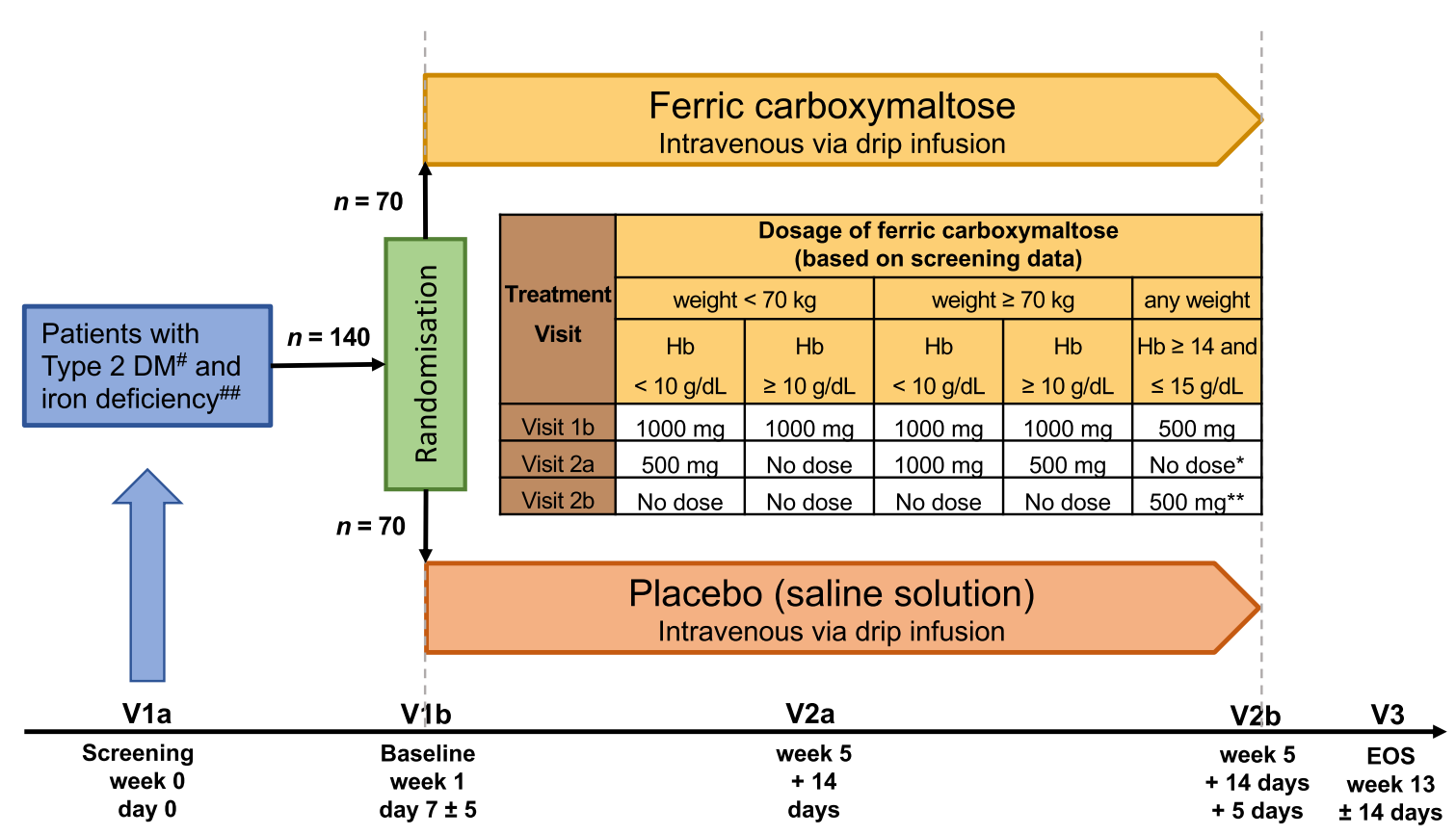

Fig. 1 CLEVER study design. ${ }^{\#}$ Defined as $\mathrm{HbAlc} \geq 48 \mathrm{mmol} / \mathrm{mol} \quad(6.5 \%)$ and $<69 \mathrm{mmol} / \mathrm{mol}$ (8.5\%). \#\#Defined as serum ferritin $<150 \mathrm{ng} / \mathrm{mL}$ or transferrin saturation $<25 \%$ if hemoglobin $<14 \mathrm{~g} / \mathrm{dL}$ or serum ferritin $<100 \mathrm{ng} / \mathrm{mL}$ or transferrin saturation $<20 \%$ if hemoglobin $\geq 14 \mathrm{~g} / \mathrm{dL}$ and $\leq 15 \mathrm{~g} / \mathrm{dL}$.
${ }^{*}$ Control parameter: ferritin and transferrin saturation. ${ }^{* *}$ If still iron deficient at V2a [serum ferritin $<150 \mathrm{ng} / \mathrm{mL}$ or transferrin saturation $<25 \%]$, an additional dose of $500 \mathrm{mg}$ ferric carboxymaltose is given at $\mathrm{V} 2 \mathrm{~b}$, otherwise it is not 
Table 2 Key inclusion and exclusion criteria

Key inclusion criteria

Key exclusion criteria
Men and women older than 18 years

Diagnosis of type 2 diabetes and iron deficiency defined as follows:

$\mathrm{HbAlc} \geq 48 \mathrm{mmol} / \mathrm{mol}(6.5 \%)$ and $<69 \mathrm{mmol} / \mathrm{mol}(8.5 \%)$

Serum ferritin $<150 \mathrm{ng} / \mathrm{mL}$ or transferrin saturation $<25 \%$ if hemoglobin $<14 \mathrm{~g} / \mathrm{dL}$

Serum ferritin $<100 \mathrm{ng} / \mathrm{mL}$ or transferrin saturation $<20 \%$ if hemoglobin $\geq 14 \mathrm{~g} / \mathrm{dL}$ and $\leq 15 \mathrm{~g} / \mathrm{dL}$

Continuous subcutaneous insulin infusion

Thalassemia

Hemoglobin $>15 \mathrm{~g} / \mathrm{dL}(\geq 9.31 \mathrm{mmol} / \mathrm{L})$

C-reactive protein $>15 \mathrm{mg} / \mathrm{L}$

Change in HbAlc of more than $\pm 0.3 \%$ within the last 3 months

Hypersensitivity to ferric carboxymaltose or to any of the excipients of the study medication

Known serious hypersensitivity to other parenteral iron products

History of acquired iron overload

History of erythropoietin-stimulating agent, IV or high-dose oral iron therapy or blood transfusion $<12$ weeks prior to randomization

Body weight $\leq 40 \mathrm{~kg}$

Chronic or active liver disease

Vitamin B12 and/or serum folate deficiency

Current malignancy under treatment

Renal function GFR $<30 \mathrm{~mL} / \mathrm{min} / 1.73 \mathrm{~m}^{2}$

Significant major cardiovascular disease ongoing or in the past 3 months

Polyneuropathy without ischemia

Pregnant or nursing (lactating) women

Any person not willing to use adequate contraceptive precautions during the study and for up to 5 days after the last scheduled dose of study medication
Open Access. This article is distributed under the terms of the Creative Commons Attribution-NonCommercial 4.0 International License (http://creativecommons.org/licenses/ by-nc/4.0/), which permits any noncommercial use, distribution, and reproduction in any medium, provided you give appropriate credit to the original author(s) and the source, provide a link to the Creative Commons license, and indicate if changes were made. 